\title{
A Cognitive Approach to the Instruction of Phrasal Verbs: Rudzka-Ostyn's Model
}

\author{
Ghuzayyil Mohammed Al-Otaibi \\ King Saud University
}

\begin{abstract}
Correspondence concerning this article should be addressed to Ghuzayyil Mohammed Al-Otaibi, Department of English Language and Translation, College of Languages and Translation, King Saud University, 11451.E-mail: galotaibi@ksu.edu.sa
\end{abstract}

\begin{abstract}
English as a Foreign Language (EFL) learners find some phrasal verbs problematic because of their idiomatic and polysemous nature. They are frequently used in spoken English and textbooks suggest an arbitrary way in teaching them. Cognitive linguists proposed that the particle plays a major role in determining the meaning of such phrasal verbs. This study investigated the effectiveness of a cognitive approach (i.e., Rudzka-Ostyn's Model) in teaching taught and new phrasal verbs including metaphorical ones. Using a list of frequent phrasal verbs, a quasi-experimental design was used in which an experimental group was required to create mind maps of the common meanings of each particle with example phrasal verbs. The control group, on the other hand, was asked to memorize the frequent senses of the most frequent phrasal verbs along with their translations. The experimental group did not outperform the control group on the post-test. This was attributed to a number of problems such as the fact that some senses given by some particles are not outlined in Rudzka-Ostyn's Model. Further, the analytical procedure followed by students to cognitively understand phrasal verbs should be made explicit and address the interaction between the verb and the particle. Additionally, following a cognitive approach, instructors should focus more on the particles up and out since they have many senses and contribute a lot to phrasal-verb formation.
\end{abstract}

Keywords: cognitive linguistics, foreign language learners, metaphorical meaning, particle, phrasal verbs, vocabulary learning

\section{Introduction}

Phrasal verbs are considered to be troublesome for English as a Foreign Language (EFL) learners. They are of a huge number and very common in spoken English. Thus, Celce-Murcia and Larsen-Freeman (1999) claimed that phrasal verbs are "ubiquitous" (p. 425). Gardner and Davies (2007) supported Celce-Murcia's and LarsenFreeman's argument that learners may encounter one phrasal verb in every 150 words of an English text. As foreign learners choose to avoid them (Dagut \& Laufer, 1985; Hulstijn \& Marchena, 1989; Laufer \& Eliasson, 1993; Liao \& Fukuya, 2004), English native speakers continue to coin more phrasal verbs with ease (Bolinger, 1971; Zareva, 2016).

Further, phrasal verbs are often polysemous and they give a new meaning a new meaning each time they are used in a different context. In a corpus-based study, Gardner and Davies (2007) identified about five meanings for each frequently used phrasal verb (p. 353). In addition, learners found phrasal verbs difficult to interpret because of their unpredictability and non-compositionality (Celce-Murcia \& Larsen-Freeman, 1999; Cornell, 1985; Moon, 1997; Side, 1990). Thus, countless number of papers have been published to discuss their semantic and syntactic intricacies (Dehé, 2002; Jackendoff, 2002). Moreover, their presentation in textbooks emphasizes their arbitrariness and suggests an unsystematic way in teaching them (e.g., Cornell, 1985; Darwin \& Gray, 1999; Gardner \& Davies, 2007; Moon, 1997; Tyler \& Evans, 2004).

Hence, the present study explores the efficiency of the cognitive approach suggested by Rudzka and Ostyn (2003) in teaching phrasal verbs for EFL learners. Rudzka and Ostyn's (2003) cognitive method was specifically selected for its emphasis on the role that particles play in determining phrasal verb meaning. More specifically, the purpose of the study is twofold. First, it explores the effect of the cognitive approach on students' retention 
of phrasal verb meaning. It also examines the effect of the approach on students' ability in figuring out the meaning of new phrasal verbs that were not explicitly taught in class.

\section{Phrasal Verbs}

A phrasal verb (particle verb as suggested by Dehé, 2002 or Pelli's, 1976, verb-particle construction) is a construction made of a verb and a particle (i.e., an adverb and/or a preposition). Such multi-word verbs behave as a single syntactic, semantic unit (Darwin \& Gray, 1999; Quirk, Greenbaum, Leech, \& Svartvik, 1985). Cornell (1985) claimed that most phrasal verbs are nonidiomatic because their meaning can be derived from that of the proper verb. However, others argued that their meaning is sometimes non-compositional and hence unpredictable. Thus, Dagut and Laufer (1985, p. 74) divided phrasal verbs into three categories: (a) literal (i.e., phrasal verbs whose meaning is the outcome of the meaning of the individual words, e.g., come out, come in, etc.); (b) figurative or idiomatic (i.e., verbs such as stuck up, turn up, let down, patch up, etc., with components contributing a different meaning from that of the individual parts; and (c) completive or aspectual verbs (e.g., start out, eat up, carry on, etc.) with particles indicating completing, starting, or continuing the task.

By the same token, some researchers such as Jackendoff (1997), Celce-Murcia and Larsen-Freeman (1999) and Armstrong (2004) argued that the grouping of phrasal verbs should consider the role played by the particle attached to the verb. Thus, phrasal verbs can retain their meaning and the particle is merely directional (e.g., come back) or the verb gives its literal meaning (e.g., read through), whereas the particle gives an aspectual or redundant meaning, and hence such verbs are termed semi-transparent. Nonetheless, the majority of phrasal verbs are idiomatic and non-transparent (e.g., make up for compensate).

\section{Traditional Approaches to Phrasal Verbs}

As stated above, traditional approaches (e.g., Fraser, 1976) to the semantics of phrasal verbs viewed them as non-compositional expressions and that the particle plays no role in their meaning. Thus, a number of educators and linguists (e.g., Cornell, 1985; Darwin \& Gray, 1999; Gardner \& Davies, 2007; Moon, 1997; Tyler \& Evans, 2004; Strong \& Boers, 2019) criticized the approach used to present phrasal verbs in textbooks. Phrasal verbs are listed in sentences with their definitions in parentheses and lessons are followed by gap-fill exercises. As stated by Moon (1997), "phrasal verbs are often presented as arbitrary combinations which cannot be analyzed and rationalized" (p. 46). Hence, conventional teaching methods suggest that phrasal verbs should be learnt mechanically and that any conceptual analysis of such constructions is futile. As a result, learners will continue to struggle with phrasal verbs used in other contexts beyond their textbook's scope (van der Veer, 2000).

\section{Cognitive Linguistic Approaches to Teaching Phrasal Verbs}

The interest in teaching phrasal verbs using the cognitive approach grew out of Langacker's effort in linking language learning to the cognitive processes in the human mind. According to cognitive linguists, linguistic structures are motivated by cognitive processes, such as metaphorization, and that our conceptual system is fundamentally metaphorical. Humans use expressions referring to concrete entities to understand abstract concepts (Lakoff, 1987; Kövecses, 2005, p. 14). Hence, cognitive linguists use the source domain (i.e., concrete objects) to better understand the target domain (i.e. abstract notions such as emotions) (Kövecses, 2005). The prevalence of metaphor in language makes language learning a challenging task (Littlemore \& Low, 2006).

Hence, cognitive pedagogists believed that metaphor, conceptualization and symbolism should be emphasized in teaching language (e.g., Gibbs, 1994; Johnson, 1987; Lakoff, 1987; Lakoff \& Johnson, 1980; Langacker, 1987, 2002 ) and that L2 instruction should consider this cognitive approach to language (Achard, 2008; Achard \& Niemeier, 2004). Furthermore, cognitive linguists noted that educators should identify for students the core meaning of a word as its prototypical meaning and then point out other meanings as extensions (Cs'abi, 2004; Verspoor \& Lowie, 2003). Further, Morgan (1997) stated that metaphorical meaning is conveyed through the verb, its particle, or both. Lindner (1981) stressed the importance of mapping spatial relations and metaphorical extensions onto image schemata and that particles contribute a bigger portion of meaning. Cognitive linguists noted that particles are stored in the lexicon in a systematic, rule-governed way and hence they challenge the previous view that argued for their arbitrariness (Tyler \& Evans, 2004). As for metaphorical phrasal verbs, Lakoff and Johnson (1980) pioneered the conceptual metaphor theory which suggested that the human cognition is 
essentially metaphorical. Johnson (1987) believed that image-schemas are the building blocks of figurative phrasal verbs and more attention should be drawn to particles to give visual representations of image-schemas.

Among the most influential contributions to the semantics of phrasal verbs are those by Lakoff (1987), Brugman and Lakoff, (1988), Lindner (1981), Rudzka-Ostyn (2003), and Tyler and Evans (2003). Analyzing the particle over, Lakoff (1987) suggested an image schema of a trajector and a landmark. A landmark can be horizontally or vertically extended. The sentences, "The bird flew over the yard" and "The butterfly flew over the wall" are examples of horizontal and vertical extensions, respectively. In some other cases, there is a contact between the trajector and the landmark as in, "John walked over the hill".

However, Tyler and Evans (2003) provided a comprehensive model that accounts for the polysemic nature of particles called the Principled Polysemy Model. As noted by Tyler and Evans (2003), meanings of prepositions are closely related to our embodied experience and our spatial conceptualization of the physical world around us. Thus, over can have five distinct senses: (a) above and beyond, (b) on the other side of, (c) completion, (d) transfer and (e) temporal. Central to Tyler and Evans' (2003) model is establishing the basic meaning, which should meet three criteria. For example, the basic meaning is the oldest sense attributed to the particle, the predominant (i.e., the common one) and the one peculiar to the particle. Tyler and Evans (2003) added that the central meaning can be spatially configured (i.e., of the trajector and its landmark) along with its functional element. Consider, for example, the particle over which denotes a sense of proximity or that in which "the trajector and the landmark are in each other's sphere of influence" (p.67).

\section{Rudzka and Ostyn's Word Power}

Rudzka and Ostyn's (2003) Word Power: Phrasal Verbs and Compounds is the first textbook on teaching phrasal verbs using a cognitive approach. Rudzka and Ostyn's (2003) model is based on Lakoff's conceptual metaphor where source domains (i.e., concrete) are used to understand target ones (i.e., abstract) and hence our bodily experience that is of spatial, concrete meaning can be extended to understand abstract states. Thus, the human body as well as the mind are containers. Consider, for instance, the difference between "The little girl stuck out her tongue" and "She thought out a solution to the problem".

The textbook is intended for post-intermediate and advanced students of English and contains about 1,100 phrasal verbs and compounds used with 17 particles and/or prepositions. The authors used insights drawn from the field of cognitive linguistics, such as the central role of the particle, to determine the metaphorical meaning of phrasal verbs. Hence, Rudzka and Ostyn (2003) divided chapters by particles and explained first those with literal meaning before going on to extensions. They emphasized imagery using diagrams containing image schemas and utilized conceptual metaphor where situations and states were viewed as containers.

Using techniques recommended by applied linguists, Rudzka and Ostyn (2003) argued that advanced students will learn metaphorical phrasal verbs if they are focused upon explicitly (i.e., through tests and exercises) and their instruction is systematized. Furthermore, such words are well-learnt if students write them out and activate them orally (Garnier \& Schmitt, 2016; Wang, 2009). Therefore, words should be embedded in contexts and taught with their collocates. The book contains a number of activities that can be done horizontally (i.e., with students) or vertically (i.e., the instructor). An important type of exercise developed by Rudzka and Ostyn (2003) is called exetests. An exetest is a fill-in-the-gap exercise of a number of sentences where students need to choose the correct phrasal verb. The first letter of the phrasal verb is given between parentheses and in some cases no clue is given. As reported by Kurtyka (2001) and Thom (2017), such exercises help in learning phrasal verbs and retaining their meaning.

\section{Previous Studies on the Cognitive Instruction of Phrasal Verbs}

There are a few studies in the literature that have followed the cognitive approaches cited above in teaching phrasal verbs to EFL learners. For example, Kövecses and Szab'o (1996) worked with Hungarian learners of English to compare two groups learning idiomatic phrasal verbs. One group was given a list of phrasal verbs with their Hungarian translations, whereas the second was instructed through orientational metaphors (i.e., concepts are spatially represented) (Lakoff \& Johnson, 1980). In a gap-filling exercise, researchers reported that the latter outperformed the former, though the test included other new phrasal verbs. However, they focused 
only on 10 phrasal verbs with the particles up and down. Likewise, on a text-based gap-filling exercise, Boers (2000) compared the performance of L1 French EFL learners in a group that learned through orientational metaphor to one that learned through textbook explanation of multi-word verbs. He reported that the metaphor group excelled over the other with respect to their performance on previously taught words. Nonetheless, the cognitively instructed group performed comparably to the other in terms of new multi-word constructions. Nevertheless, Boers' (2000) in-class instruction handled 26 phrasal verbs with off, out, on, in, up, down, through. Further, Nhu and Huyen (2009) used the cognitive approach by Lakoff and Johnson (1980) to teach phrasal verbs having the particles in, out, up, and down to Vietnamese students who were English majors at Thuc Hanh High School. Participants were asked to fill in the blanks with phrasal verbs or particles. Results showed that the experimental group outperformed the control group at guessing the meaning of unfamiliar phrasal verbs.

Similarly, Talebinejad and Sadri (2013) focused on 20 phrasal verbs with the two particles up and down and worked with 60 Iranian EFL learners who were at the intermediate level of language proficiency. Students were assigned to two groups (i.e., experimental and control) where the control group was given lists of phrasal verbs with their dictionary definitions. The experimental group, however, was instructed using the cognitive model suggested by Tyler and Evans (2003). T-test results showed that the treatment group excelled at recalling the meaning of learnt phrasal verbs and they successfully transferred their cognitive knowledge of learnt phrasal verbs to unfamiliar ones. By the same token, White (2012) worked with two groups of EAP (English for Academic Purposes) university L2 learners mainly from China, South Korea and Taiwan. The study was carried out over seven weeks. The researcher adopted the cognitive approach along with Vygotsky's sociocultural theory to reach what is called conceptual mediation, where students are prompted to create their own image schemas. The researcher followed four steps in which students were exposed to phrasal verbs in class as constructions that can be "conceptually motivated" (p. 422). Then students were required to collect phrasal verbs and discuss their meanings in small groups. After that, the researcher prompted students to draw and share phrasal verb meanings. When sharing meaning, students were allowed to refine their understanding of phrasal verbs. The researcher emphasized that inferencing (i.e., not memorization) is a good way to deal with figurative meaning as suggested by Lazar (1996). The technique would also promote longer retention. The test administered after the treatment consisted of contextualized, new phrasal verbs where students were asked to infer their meaning. T-test results showed that students' performance on the post-test was modest and hence it was not significant. The researcher suggested that instructors should focus on frequent phrasal verbs that have been emphasized in corpus-based studies or include those found in course books. It is important to note that White (2012) considered six particles (i.e., up, out, through, off, down, in) and discussed in class only phrasal verbs collected by students.

In another study by Karahan (2015), 63 Turkish EFL learners studying at a public university took part in a research investigating the effectiveness of the cognitive approach (i.e., orientational metaphors) in teaching phrasal verbs with up, down, into, out, off. The author did not follow a particular approach. On a gap-filling exercise, the treatment group did not perform significantly better than the control group, which was encouraged to give the translation of each phrasal verb with an example sentence. The researcher recommended that dividing phrasal verbs according to the meaning of their particles will make explicit phrasal-verb instruction more efficient.

More recent investigations were by Milošević and Pavlović (2017) and Lu and Sun (2017). Milošević and Pavlović (2017) explored the semantics of phrasal verbs related to plant growth focusing on those having the particles out, off, up, through, in and away. Though Milošević and Pavlović (2017) did not adopt a specific cognitive model, they noted that phrasal verbs contribute a general meaning and a specific one. The general meaning which can be metaphorical results from the particle, whereas the specific meaning results from conceptual metonymies peculiar to the verb. For instance, in sprout out, stem out and bud out, out contributes a meaning of accessibility besides the specific meaning manner of action for the action given by the verb. On the other hand, Lu and Sun (2017) worked with Chinese learners of English to determine the effect of the cognitive approach on students' retention of phrasal verb meaning. Similar to other researchers, Lu and Sun (2017) referred to the cognitive approach they selected as orientational metaphor. They took into consideration other variables such as students' English proficiency level and types of memory involved. Results indicated that orientational metaphor has a positive effect on students' long term memory. Postgraduate students were better than juniors on the post-tests in terms of accuracy. However, the experimental group did not perform better than the control group.

Other similar studies to the present study have been conducted by Yasuda (2010) and Spring (2018). Yasuda (2010) worked with 115 Japanese students to test the efficiency of orientational metaphors in teaching 21 
idiomatic phrasal verbs with the particles up, down, into, out and off. The taught phrasal verbs were selected because they were frequently used in idiom textbooks for Japanese students. The control group was required to memorize Japanese translations of the phrasal verbs, whereas the experimental group were instructed to pay attention to the particle to determine the meaning of the whole string. In-class instruction for both groups did not last for more than 10 minutes. In a gap filling exercise, students were asked to fill in the blanks with appropriate particles. The test included 15 explicitly taught phrasal verbs and 15 new phrasal verbs. Results indicated that the experimental group performed better than the control group. Spring (2018), on the other hand, benefited from Garnier and Schmitt's (2015) list of frequent phrasal verbs to extract another list of frequent particles, namely up, down, in, out, on, off, back, away, after, under, over, across, along, about/around, through, apart, together. Believing that the meaning of a phrasal verb results from a conflation between the verb and its particle (Talmy, 1985), Spring (2018) proposed some frequent senses for such particles to account for 95\% of phrasal verb meanings. Thus, Spring's (2018) approach was based corpus linguistics and Talmy's cognitive theory of event conflation. According to Talmy (1985), since English is a satellite-framed language, motion, change and temporality are conveyed by the particle. Spring (2018) conducted his study with 75 Japanese learners of English in which the experimental group was taught phrasal verbs using the conflation method, whereas the control group was instructed on phrasal verbs as whole units. He found that the conflation group outperformed the control overall, but especially on uncommon phrasal verbs, which were not explicitly taught. However, Spring (2018) also stressed the need for more experimentation on the cognitive instruction of phrasal verbs to learners with many different L1s because he felt that the effectiveness of such lessons may vary depending on the learner's L1 language type.

As shown above, the majority of studies considered a few particles (e.g., White, 2012; Boers, 2000) and a few phrasal verbs (e.g., Talebinejad \& Sadri, 2013; Kövecses \& Szab’o, 1996), but they all used a gap-filling exercise to test participants' knowledge of the particle. The adopted approach in many studies is orientational metaphors (e.g., Kövecses \& Szab'o, 1996; Boers, 2000) as proposed by Lakoff and Johnson (1980). Furthermore, some investigations (e.g., Yasuda, 2010; Spring, 2018) suggested an in-class instruction of shorter duration. However, multiple contacts of longer duration are recommended to ensure effective learning and retention of explicitly taught phrasal verbs (Nation, 1990). As opposed to previous studies, the present study was of longer duration, of a different cognitive approach and addressed 150 frequent phrasal verbs along with 12 particles. Similar to Spring's (2018), the present study was based on Liu's (2011) list which was derived from the Corpus of Contemporary American English (COCA) and the British National Corpus (BNC). The list is of 150 frequentlyused phrasal verbs and their very frequent senses proposed by Garnier and Schmitt (2015). Additionally, akin to Yasuda's (2010) and Spring's (2018), the pre- and post-tests were of taught and new phrasal verbs where participants were required to fill in the gaps with particles.

Corpus-based examination of the most common phrasal verbs provides helpful answers for struggling teachers. Lists have been proposed by Biber, Johansson, Leech, Conrad and Finegan (1999), Gardner and Davies (2007) and Liu (2011) where frequency, as a parameter, determines inclusion in such lists. However, with the development of such lists, learners have a greater chance to memorize such two-verb words as whole units (Spring, 2018). Thus, adopting a cognitive model that considers the role of the particle in determining phrasal verb meaning was essential.

Since English is a satellite-framed language (i.e., the meaning of the event is embedded in the verb and its particle where the latter includes the path of motion), Arab learners are expected to face difficulties with phrasal verbs because Arabic is a verb-framed language where the path of motion is encoded in the verb (Talmy, 1985). Selecting a cognitive model that relies heavily on the meaning of one component (i.e., the particle) might help such learners.

As noted above, many native speakers and learners of English struggle as they try to learn and retain the meanings of metaphorical phrasal verbs. Rudzka and Ostyn (2003) attributed the source of this difficulty to the fact that the particle itself is used metaphorically. That is, its literal meaning is extended to abstract domains related to emotions, feelings, thoughts, attitudes and intentions. Hence, the method adopted in the present study was the cognitive approach to teaching phrasal verbs suggested by Rudzka and Ostyn (2003) in their book, Word Power: Phrasal Verbs and Compounds. The focus was on phrasal verbs where the authors gave a major role to the particle in determining the meaning of phrasal verbs. The authors used Figure 1 below as the basis to understand different types of phrasal verbs especially transparent ones. 


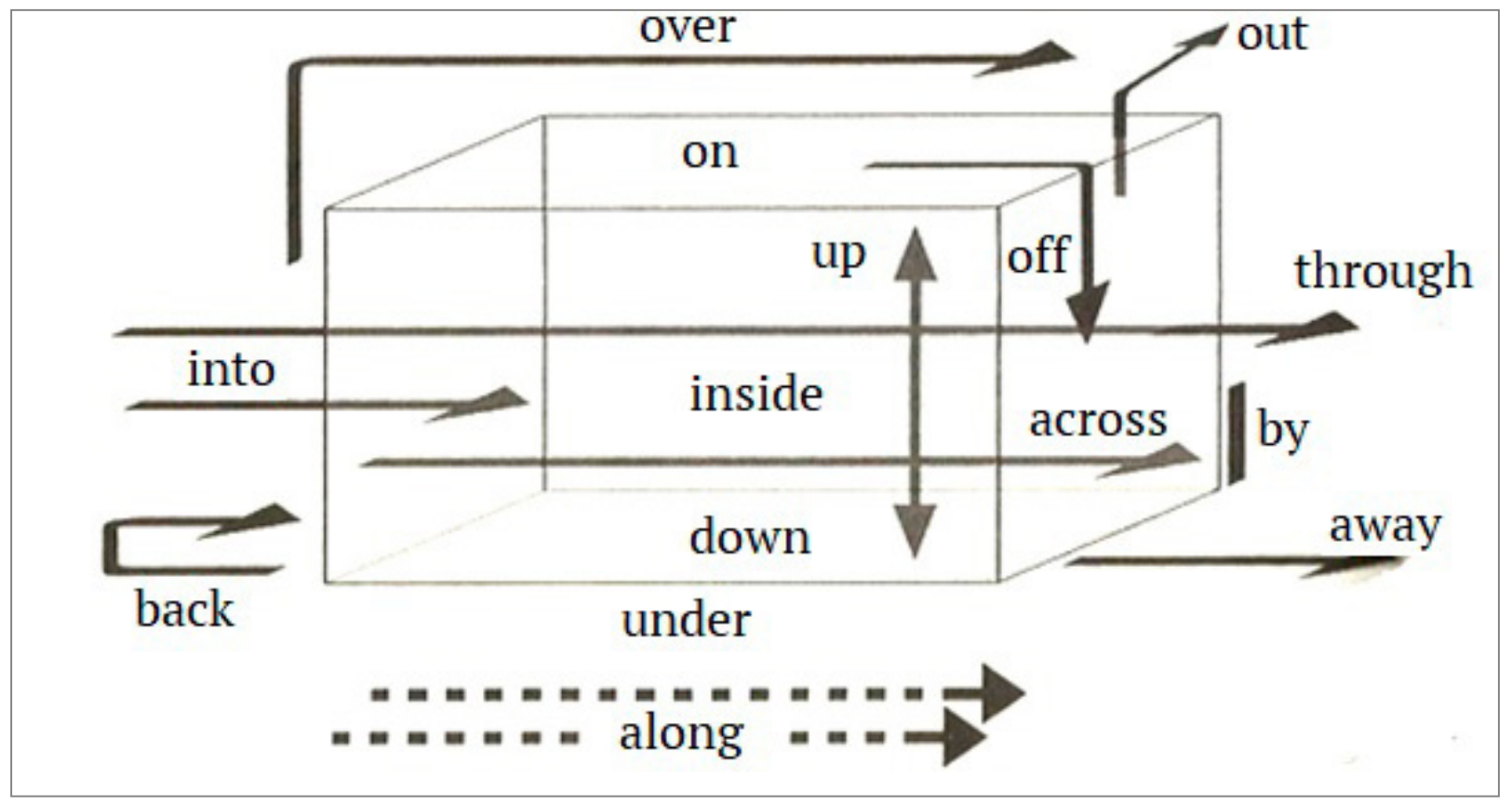

Figure 1. Graphical presentation of particles' meanings (Rudzka-Ostyn, 2003, p. 4).

\section{Research Questions}

Based on the research objectives stated above, the present study aimed to answer the following questions:

1. Can Rudzka and Ostyn's (2003) Word Power Approach help EFL students retain the meaning of explicitly taught phrasal verbs?

2. Is their approach effective in helping students conjecture the meaning of new phrasal verbs?

\section{Materials and Methods}

\section{Materials}

In Rudzka and Ostyn (2003), chapters are organized around particles and for each particle a list of possible meanings is included. In this study, the focus was on the 12 particles (i.e., up, back, out, in, on, down, off, through, about, around, along, over) occurring frequently in Liu's (2011) list. Other particles discussed in Rudzka and Ostyn (2003) and were not in the list such as across, by, away, into were ignored besides ahead since it is used in Liu (2011) only once with the verb go as in go ahead.

The meanings of phrasal verbs listed in Rudzka and Ostyn (2003) are of limited number and range from transparent to metaphorical ones. Transparent and metaphorical extensions correspond to Spring's (2018) motion and change meanings of particles, respectively. For example, off can give any of the following meanings: (a) loss of spatial contact (e.g., peel off); (b) separation as loss of contact (e.g., carry off); (c) separation as interruption of flow or supply (e.g., turn off); and (d) separation due to motion away from its former state, condition or point of reference (e.g., put off) (Rudzka \& Ostyn, 2003). Spring (2018) referred to such meanings in terms of motion and change, as move to a position of not touching and become unattached. To aid in learning and understanding, each meaning in Rudzka and Ostyn's (2003) book is supported by example phrasal verbs embedded in sentences and a schema (i.e., a drawing or a mental representation of a spatial relation between containers and moving entities). Using Lakoff's (1987) terms, moving entities are trajectors (i.e., entities in the foreground represented by a small dark rectangle) and containers (i.e., background entities represented by rectangles) are landmarks (Thom, 2017). Figure 2 below is illustrative. 


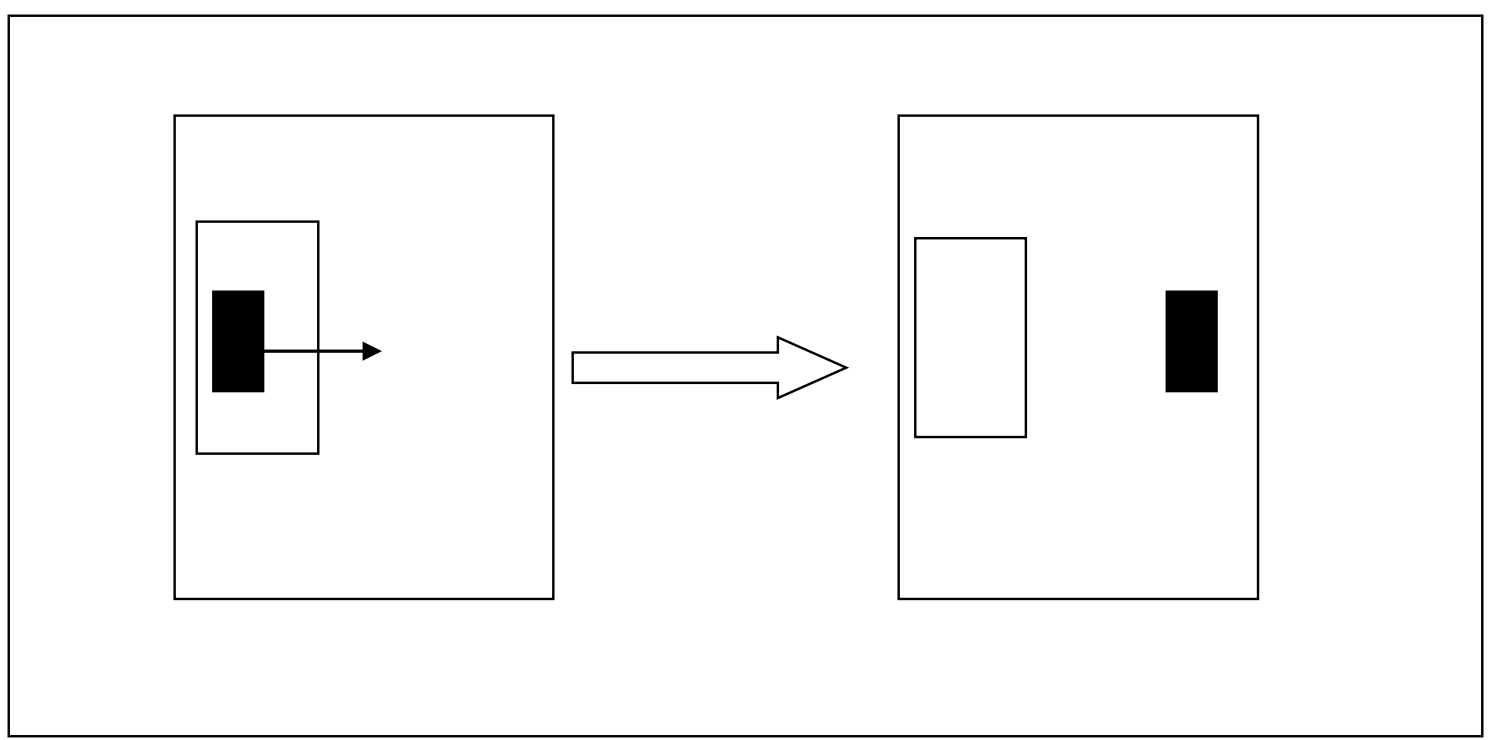

Figure 2. Schematic representation of the particle 'out' (Rudzka-Ostyn, 2003, p. 18).

Pre- and post-tests (see Appendix A) consisted of 20 items. They were similar to Rudzka and Ostyn's (2003) exetests, where students were required to fill in the blanks with particles. The first pair of tests (pre-test and post-test) consisted of 10 items taken from Liu's list or explicitly taught in class. On the other hand, the second group of tests (pre-test and post-test) was composed of 10 new phrasal verbs and students of the experimental group were expected to guess the meaning of such phrasal verbs based on their knowledge of the meaning of the particle. There was a period of six weeks between the pre- and the post-test. To achieve test $\backslash$ re-test reliability, the pre- and post-test was piloted with a sample $(n=15)$ of a writing class who was not part of the present study. It was administered to the same group on two different occasions (two-week interval). Scores obtained from these two administrations were correlated using the Pearson product-moment correlation coefficient. Results revealed that the tests showed a high degree of correlation which suggested that students performed similarly on both occasions. Hence, the test scored $(r=0.70)$ and thus it is considered to be reliable.

\section{Participants}

Participants were of two intact groups and were the researcher's students. They were all female EFL Arab college students taking a vocabulary course at the College of Languages and Translation (COLT) for their first time during the first semester of the academic year 2016/17. They were between the ages of 19 and 21. Besides taking an English subject for six years (i.e., middle and high school), participants finished an intensive program in English called the Preparatory Year Program (PYP) where they received instruction (i.e., mathematics, science, etc.) in English. Students were not admitted to COLT if they did not score five in the International English Language Test System (IELTS) ${ }^{1}$. Additionally, they should score a grade point average (GPA) of 4.80 out of 5 (KSU Deanship of Admission and Registration, 2018) ${ }^{2}$. According to the Common European Framework of Reference for Languages (CEFR) (2018) ${ }^{3}$, a band score of five can be compared to CEFR's B Levels (i.e., independent user) where the language learner can understand general topics, deal with travel situations, describe their experiences and write on topics of interest. Upper intermediate learners at these levels can understand the main ideas of a technical text, write on a wide range of topics in a detailed manner and interact with natives without any difficulty.

This study began with 62 participants, but the total number of subjects became 51 because of students' irregular attendance and withdrawal, which affected the process of obtaining data. As mentioned above, participating subjects were of two groups: an experimental group $(n=26)$ and a control group $(n=25)$. The control group received

\footnotetext{
British Council. (2018). IELTS band scores explained. Retrieved from https://takeielts.britishcouncil.org/find-out-about-results/ understand-your-ielts-scores/overall-band-scores-explained

2 Deanship of Admission and Registration. (2018). Online cutoff. Retrieved from https://dar.ksu.edu.sa/ar/node/771

3 Common European Framework. (2018). How should the CEFR be used by recognizing institutions wishing to set language ability requirements? Retrieved from https://www.ielts.org/ielts-for-organisations/common-european-framework
} 
traditional in-class instruction where they were asked to add their translations to Liu's (2011) list and memorize all the definitions of the most common phrasal verbs in English. The experiential group, on the other hand, was required to create mind maps where examples of phrasal verbs were clustered around each English particle. They created 12 maps corresponding to 12 particles (i.e., along, around, through, back, down, about, in, off, out, over, on, up) in English. The essence of the present study was to help students understand the metaphorical meanings of phrasal verbs by extending the literal meanings of all the 12 particles to abstract domains including emotions, thoughts, feelings, etc. The senses of the particles outlined in Rudzka and Ostyn (2003) are around 50. The focus was on the 12 particles advanced above because they contribute immeasurably to the formation of the common 150 phrasal verbs suggested by Liu's (2011) list based on his corpus investigation. A lot of phrasal verbs and their common senses, especially literal ones, were familiar to students such as pick up, come back, stand up, find out, etc. It is important to note that this study did not utilize random distribution of participants because they were assigned classes independently of the experiment, but it did fall into the realm of nonequivalent-control-group design, which is generally used and accepted in many educational experiments (Best \& Kahn, 1986).

\section{Procedure}

The researcher met both groups on the same day that they both were pre-tested. Using Liu's (2011) list, the control group was asked to create a table of phrasal verbs, including their definitions and example sentences besides their translations. On the other hand, the experimental group was instructed to create 12 mind maps corresponding to 12 particles (e.g., down, up, out, in, on, etc.). Such particles make up frequent phrasal verbs found in Liu's (2011) list. The resultant map included the particle as its central bubble and other bubbles of key senses of the particle. For the experimental group, the emphasis was on particles' possible senses and not on the definitions of common phrasal verbs. According to cognitive linguists, understanding particles would hopefully help students derive the meanings of new phrasal verbs.

The key meanings of particles were taken from Rudzka and Ostyn (2003) where they are illustrated through schemata. Students were instructed to match the verbs in the list, with respect to the particle, to their corresponding key senses. Adding more definitions or example sentences peculiar to each phrasal verb was acceptable. Students of the experimental group could create their maps using a computer program or simply by hand. Students of both groups took the responsibility of dividing the work among themselves. The mind map below (Figure 3) is illustrative. It was created as a model by the researcher using a mind-mapping software called FreeMind.

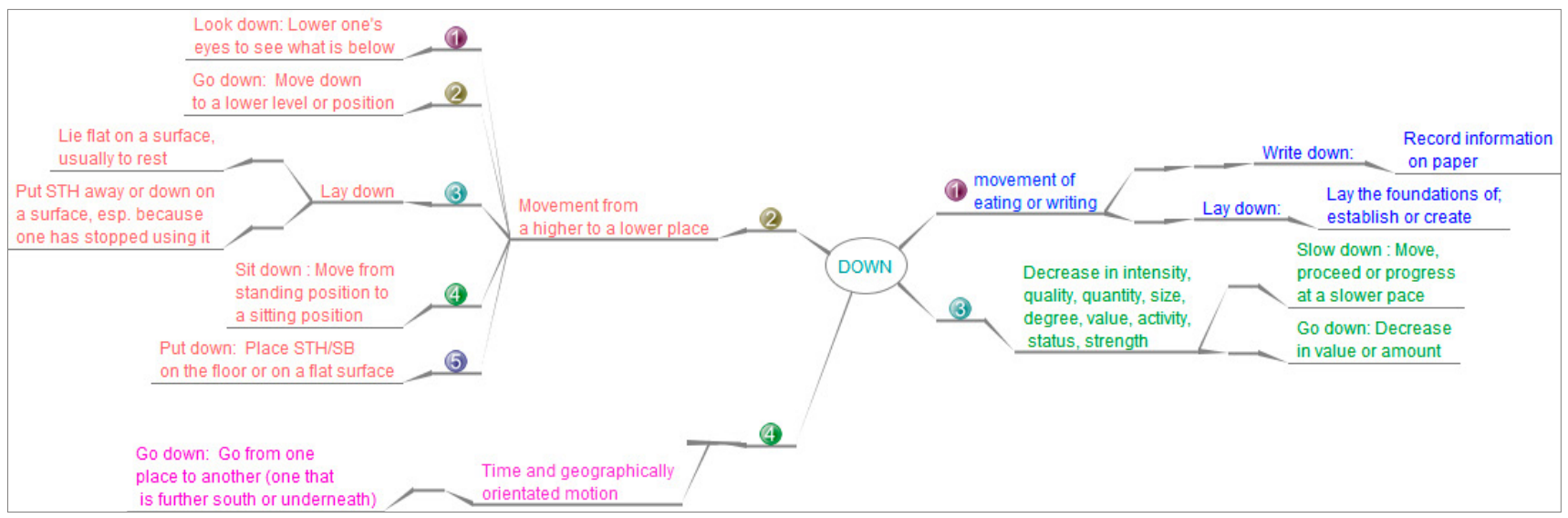

Figure 3. A mind map showing all the possible key senses of the particle 'down' with example phrasal verbs.

Furthermore, each sub-group in the experimental group (i.e., responsible of one-particle map) was asked to solve problems as they were working on the same map and negotiate meaning (i.e., which phrasal verb meaning is best expressed by which particle sense). The instructor's input was kept to a minimum. However, upon submission, students of both groups received feedback where they were required to make some modifications. In addition, students of both groups were instructed to check a recently-created online dictionary (PHaVE Dictionary, 2019) that includes (besides definitions and example sentences) translated sentences having common phrasal verbs ${ }^{4}$.

\footnotetext{
${ }_{4}$ PHaVE Dictionary. (2019). 150 most common phrasal verbs and their most common meanings. Retrieved from http://phave-dictionary. englishup.me/
} 
In addition, the Dictionary provides guidelines for teachers as well as learners on how to use the list along with exercises by Glenys Hanson and Michelle Worgan ${ }^{5}$. The verbs in the Dictionary are in the order from the most common to the least common as suggested by Garnier and Schmitt (2015).

Using paired t-tests, learner performance on pre- and post-tests was evaluated for each group. Furthermore, two-way analysis of variance (ANOVA) tests with one-repeated measure were used to check for a significant interaction between teaching style and improvement to see if one group improved more significantly than the other. The between-groups independent variable was the teaching style adopted for each group (i.e., the cognitive approach selected for the experimental group vs. the translation method for the control group), whereas the within-groups independent variables were time (i.e., pre- and post-test results) and exposure (i.e., new or explicitly taught phrasal verbs). On the other hand, the dependent variable was participants' performance on a gap-filling task. Confidence intervals were set at the $95 \%$ confidence level.

\section{Data Analysis}

Paired-samples t-tests showed that both groups improved significantly on phrasal verb knowledge overall (i.e., on both explicitly taught and new phrasal verbs). Results of pre- $(M=3.72, S D=2.31)$ and post-tests $(M=$ $6.64, S D=2.89$ ) of the control group showed significant improvement; $t(24)=-5.36, p=0.000$. Comparably, the performance of the experimental group on the post-test $(M=7.84, S D=2.86)$ was significant compared to the pre-test $(M=3.73, S D=2.66) ; t(25)=-8.66, p=0.000$. However, a two-way ANOVA showed that there was no interaction between teaching style(i.e., group) and students' performance on tests; $\left(F(1.49)=2.75, p=.104, \eta_{p}{ }^{2}=\right.$ .053 , power=.36). The partial eta-squared effect size $\left(\eta_{p}{ }^{2}\right)$ revealed that this two-way interaction accounted for only .05 of the variance in scores of the tests, which is a small effect size. In other words, no significant effect was established for groups; $F(1.49)=.83, p=.36, \eta_{p}{ }^{2}=.017$, power=.14. Both groups improved significantly from their pre- to post-tests. Since the independent variables were of less than three levels, the above-advanced results were of the sphericity assumed.

The same statistical test was performed independently for participants' scores on explicitly taught and new phrasal verbs. A paired t-test of the pre-test $(M=1.76, S D=1.16)$ and post-test $(M=3.44, S D=1.80)$ of the control group on their performance on explicitly taught phrasal verbs indicated significant improvement; $t(24)$ $=-3.83, p=0.001$. Similarly, scores of the experimental group on the pre-test $(M=1.61, S D=1.29)$ and the posttest $(M=4.11, S D=2.04)$ yielded a significant increase; $t(25)=-7.19, p=0.000$. As for new, unexposed phrasal verbs, comparing pre- $(M=1.96, S D=1.83)$ and post-test $(M=3.20, S D=1.65)$ scores of the control group showed a significant difference; $t(24)=-3.47, p=0.002$. Likewise, the performance of the experimental group showed a significant increase in the post-test $(M=3.73, S D=1.58)$ compared to the pre-test $(M=2.11, S D=1.79) ; t(25)$ $=-5.70, p=0.000$. As shown above, participants performed similarly on the tests of explicitly taught and new phrasal verbs. The mean difference between the control and experimental groups in the explicitly taught category of phrasal verbs $(M=.82)$ is statistically not significant ( $p=.148)$. Similarly, the mean difference between the control and experimental groups in the new set of phrasal verbs $(M=.68)$ is also not significant $(p=.42)$. In addition, no significant interaction was found between exposure and time; $F(1.49)=3.4, p=.071, \eta_{p}{ }^{2}=.065$, power=.44.,exposure and group; $F(1.49)=.034, p=.855, \eta_{p}{ }^{2}=.001$, power=.054 and exposure, time and group; $F$ $(1.49)=.38, p=.53, \eta_{p}{ }^{2}=.008$, power $=.093$.

\section{Results and Discussion}

Though previous research (e.g., Lakoff, 1987; Lindner, 1981; Tyler and Evans, 2003) focused on a number of particles, such as over, up, out, etc., the present study aimed to help students understand the metaphorical meanings of phrasal verbs through extending the literal meanings of particles. There are around 50 senses of the 12 particles outlined in Rudzka and Ostyn (2003). As indicated in the results above, students of the experimental group showed significant improvement in their retention of phrasal verb meanings and their extension of particles' literal senses to new ones, but they did not exhibit more improvement than the control group, taught through more conventional methods.

\footnotetext{
${ }^{5}$ Hanson, G., \& Worgan. M. (n.d). PHaVE help. Retrieved from http://phave-dictionary.englishup.me/faq/index.html
} 
There are many reasons why there was no statistically significant interaction between teaching style and improvement from pre- to post-test. First, students were required to match the senses of the most frequent phrasal verbs in English with the possible meanings of the 12 particles to create mind maps and to prepare for exams using the maps. However, students sometimes found it difficult to include all the verbs in Liu's list in one map or two (especially those with up, out and back) or include all the possible senses of polysemous phrasal verbs in such maps. Go down, for instance, has three common senses. The first one matches the first meaning of down suggested by Rudzka and Ostyn (2003) which is movement from a higher to a lower position. The second reflects the third meaning, decrease in value, whereas the third describes the second sense, geographical movement to the south. For some verbs, students were inclined to map the least common meaning or the first meaning only. However, the majority included in their maps the senses that can be easily linked to a particle's meaning.

Nevertheless, during instruction, some students mentioned that they found it difficult to decide which meaning of the particle could match which phrasal verb meaning. With the help of the teacher, students still could not see the relationship between the general sense (pertaining to the particle, found in Rudzka and Ostyn, 2003) and the specific meaning given by the phrasal verb. Consider, for example, the verb carry out (i.e., for implementing plans). According to Rudzka and Ostyn (2003), non-existence of such plans is viewed as a container and out expresses, as one of its senses, movement out of such abstract states. In this case, specifically, it might be more difficult for students to think that an abstract state (i.e., a plan in one's head) should be treated as a container. Further, the sense of the verb, make up (i.e., compensate) is not reflected by any of the senses of up identified by Rudzka and Ostyn (2003). These are moving up to a higher place or a higher degree, reaching a goal, an end or a limit, making something visible or accessible and covering an area completely. Further, as noted by Kissling (2012), not all examples cited in Rudzka and Ostyn (2003) truly represent the senses attributed to the particles.

Identifying 50 meanings for the frequent particles, Rudzka and Ostyn (2003) failed to establish a number of criteria for determining the basic sense for each particle in their book. In addition, they did not clarify how extensions are related to the central sense of the particle (Kissling, 2012). Even worse, in some cases, the authors did not give a convincing reason for each distinct meaning, and sometimes two different senses are given the same representation (Kissling, 2012). For example, in reference to out, Rudzka and Ostyn (2003) proposed that the particle may refer to entities moving out of containers (e.g., throw out, jump out, etc.), eating or inviting to eat away from home (e.g., ask out, take out, etc.), groups acting as containers (e.g., sort out, kick out, etc.), bodies and minds viewed as containers (e.g., think out, reach out, etc.), states or situations as containers(e.g., worn out, run out of, etc.) and non-existence, ignorance, invisibility, etc. as containers(e.g., find out, work out, etc.). However, Rudzka and Ostyn (2003) did not specify which sense is central, but the approach they adopted focused on concrete states (e.g., home activities, activities done outside one's home, etc.) before abstract ones (e.g., situations as containers). Further, there is a transition (e.g., one's body or mind as a container) between the two. Moreover, for off, Rudzka and Ostyn (2003) specified two similar meanings (i.e., loss of spatial contact or spatial separation, e.g., chop off, fall of, etc. and separation as loss of contact, e.g., set off, cut off, etc.). In other words, they did not differentiate between the two. They have been also given the same schematic diagram.

Rudzka and Ostyn's (2003) approach as a cognitive approach to the meaning of lexical items holds that the meaning of a phrasal-verb is partially compositional and that one can rely on pragmatics (i.e., background information and embodied experience) and cognitive mechanisms (e.g., metaphor and metonymy) to derive meaning (Evans \& Green, 2006; Goldberg, 1995; Langacker 1987, 2008; Taylor, 2002). However, Rudzka and Ostyn (2003) paid more attention to the role of the particle as the main source of meaning (Kissling, 2012) and thus they ignored the verb or how the particle and the verb interact and contribute to meaning. This finding is in line with previous research implications by Spring (2018), White (2012), Karahan (2015), Teng (2018), Conroy (2018) and Cooper (1999) who suggested that instructors should explicitly analyze how partially or fully components in a phrasal verb construction contribute to meaning.

In a research paper by Milošević and Pavlović (2017), the authors proposed that metaphor and conceptual metonymy are important mechanisms for reaching an overall understanding of phrasal verb meaning. As metaphorical meaning is given by the particle, conceptual metonymies stem from the verb. Thus, extending the literal meanings of the particle to abstract states is not enough, as suggested by Rudzka and Ostyn (2003) in their book. The semantic interaction between the verb and the particle is still essential. As noted by Milošević and Pavlović (2017), similar to particles' extensions, conceptual metonymies are of a limited number and they were outlined by Kövecses and Radden (1998). Examples of such metonymic patterns are instrument for action, agent for action, action for agent, object involved in an action for the action, etc. 
Though there are many studies that addressed the suitability of the cognitive approach to teaching polysemous phrasal verbs for native speakers of English, Lu and Sun (2017) and Spring (2018) confirmed its appropriateness for EFL learners of English, especially whose languages are characterized as verb framed. Lu and Sun (2017) added that for such learners the use of L1 to aid in phrasal verb instruction is highly recommended. Thus, focusing on EFL learners of translations, the present study might yield positive gains for the experimental group if the semantics of the verb was considered and if translations that showed the metaphorical or the metonymic relations were given in class. Spring (2018) further noted that it is essential for EFL learners to realize the typological differences between verb-framed languages and satellite-framed languages through considering the interaction between the verb and the particle. Comparable to the present study, Spring (2018) found that both groups improved significantly on explicitly taught and new phrasal verbs, but ANOVA results indicated a relationship between teaching style and improvement only for new phrasal verbs, which still confirmed the efficiency of the cognitive approach in teaching new phrasal verbs. Spring's (2018) short list of phrasal verb meanings based on Talmy's (1985) theory of event conflation might help Arab learners in conjecturing the meaning of new phrasal verbs, so they do not have to memorize 50 meanings or so.

Based on Liu's (2011) list, particles appearing frequently in phrasal verbs such as up, out, etc. are known for their polysemous nature and their dual functions. In other words, they play two functions as an adverb or a preposition (hence termed adpreps) in any phrasal-verb construction (Bolinger, 1971). Consider, for example, the sentence, "She pulled the tablecloth off the table", where off can work as part of the prepositional phrase off the table and as a phrasal verb component in pull off. In both cases, it indicates a completive meaning. Such adpreps should be given more attention in class.

\section{Pedagogical Implications}

Although the current study did not find significant interactions between teaching style and improvement, it did find significant differences in pre- and post-tests, indicating improvement, which emphasized findings of previous studies (White, 2012; Karahan, 2015) and highlights a number of implications for future research. For example, it sheds light on the importance of activating students' analytic ability to understand language patterns and internalize its rules (Skehan, 1998). As noted by Yasuda (2010), analytic thinking is an important part of students' metalinguistic knowledge essential for L2 learning. Thus, instructors are advised to employ a think-aloud procedure to refine students' understanding of such constructions and to uncover the analytical procedure followed by students (Cooper, 1999; White, 2012).

In addition, if the focus of using the cognitive approach is to help students retain specific phrasal verb meanings, the instructor can focus on the phrasal verbs in the textbook. However, if the aim is to generalize metaphorical knowledge to new phrasal verbs, the L2 teacher can extend in-class instruction to include more of the most frequent phrasal verbs. The latter is recommended due to the fact that new phrasal verbs are constantly coined. In both cases, the interaction between the verb and the particle should be addressed in class. Moreover, for highly polysemous phrasal verbs, meanings scoring more than $50 \%$ of the verb's sense distribution in Garnier and Schmitt's (2015) list are the ones to be considered. Implementing the cognitive approach in class and using a list of frequent phrasal verbs (e.g., Liu's) with different particles will help not only with figuring out the meaning of inherently metaphorical phrasal verbs but with extending metaphorical knowledge to understand compounds such as downsizing, upholding, outgoing, off-point, etc. Thus, the ability to conjecture the meaning of new phrasal verbs is very important for learners. Further, as there are many lists for frequent phrasal verbs that can guide lexicographers and educators in lexicography and curriculum design, the researcher found that phrasal verbs with the particles up, out and off should be given more importance because of their multiple meanings and the large amount of phrasal verbs including them.

Future research on phrasal verbs may address how English and Arabic share some similarities in terms of conflation patterns because recent research (e.g., Alhamdan, Alenazi \& Maalej, 2018) has proven that Arabic is not a typical verb-framed language. Thus, using a cognitive approach that draws learners' attention to the role that the particle and the verb play in determining meaning is recommended for EFL Arab learners. In addition, translating English phrasal verbs into Arabic or vice versa might highlight the similarities between such languages and how they behave typologically. 


\section{Conclusion}

Traditionally, phrasal verbs are considered to be non-compositional. Their presentation in textbook emphasizes their arbitrariness. Hence, L2 learners face problems as they try to learn and retain their meaning. The cognitive approach, however, emphasizes the role of the particle in determining the meaning of the phrasal verb (i.e., aspectual, literal and idiomatic). The researcher followed the cognitive approach suggested by Rudzka and Ostyn (2003) in their book to conduct an experiment of six weeks. The control group and the experimental one performed comparably on the post-test which was of explicitly taught and new phrasal verbs. Hence, the researcher suggested that analyzing compositionality of phrasal verbs explicitly with students may help avoid the problems outlined in the study. Further, instructors of EFL learners whose languages are not satellite-framed ought to consider the role that the verb plays in each phrasal-verb construction.

As shown above, the meaning of the particle cannot be examined without any reference to the verb. Thus, besides lists by Biber et al. (1999), Gardner and Davies (2007), Trebits (2009), Liu (2011) Akbary, Shahriari \& Hosseini Fatemi (2018) and Liu and Myers (2018) that were based on synchronic investigation of phrasal verbs, diachronic corpus investigation of phrasal verbs is still essential to minimize the number of phrasal verbs taught in class. Future research addressing the effectiveness of cognitive approaches to teaching non-transparent phrasal verbs should include lots of exercises that require students to fill in the blanks with appropriate particles. Using such exercises in class helps students retain the meaning of the particle and it encourages them to extend its meaning to similar constructions.

Despite the shortcomings mentioned above, the approach followed by the researcher would hopefully help students address the issue of learning metaphorical phrasal verbs in a systematic manner instead of viewing them as 'arbitrary combinations' (White, 2012). Outlining metaphorical relations between phrasal-verb meanings and those of particles is well-acknowledged by various researchers (Kovecses \& Szabo, 1996; Boers, 2000; Yasuda, 2010; Karahan, 2015). Though metaphoric thinking was widely considered (by L2 practitioners) as a tool peculiar to literature classes, cognitive linguistics proved its validity in L2 classes (Yasuda, 2010).

\section{References}

Achard, M. (2008). Teaching construal: Cognitive pedagogical grammar. In P. Robinson \& N. C. Ellis (Eds.), Handbook of cognitive linguistics and second language acquisition (pp. 432-455). New York, NY: Routledge.

Achard, M., \& Niemeier, S. (Eds.). (2004). Cognitive linguistics, second language acquisition, and foreign language teaching. Berlin, Germany: Mouton de Gruyter. doi: https://doi.org/10.1515/9783110199857

Akbary, M., Shahriari, H., \& Hosseini Fatemi, A. (2018). The value of song lyrics for teaching and learning English phrasal verbs: A corpus investigation of four music genres. Innovation in Language Learning and Teaching, 12(4), 344-356. doi: https://doi.org/10.1080/17501229.2016.1216121

Alhamdan, B., Alenazi, O., \& Maalej, Z. A. (2018). Motion verbs in Modern Standard Arabic and their implications for Talmy's lexicalization patterns. Language Sciences, 69, 43-56. doi: https://doi.org/10.1016/j. langsci.2018.06.001

Armstrong, K. (2004). Sexing up the dossier: A semantic analysis of phrasal verbs for language teachers. Language Awareness, 13(4), 213-224. doi: https://doi.org/10.1080/09658410408668808

Best, J., \& Kahn, J. (1989). Research in education (6th ed.). Englewood Cliffs, NJ: Prentice Hall.

Biber, D., Johansson, S., Leech, G., Conrad, S., \& Finegan, E. (1999). Longman grammar of spoken and written English. Harlow, UK: Longman.

Boers, F. (2000). Metaphor awareness and vocabulary retention. Applied Linguistics, 21, 553-571. doi: https:// doi.org/10.1093/applin/21.4.553

Bolinger, D. (1971). The phrasal verb in English. Cambridge, MA: Harvard University Press.

Barlow, M. (1996). Corpora for theory and practice. International Journal of Corpus Linguistics, 1(1), 1-37. doi: https://doi.org/10.1075/ijcl.1.1.03bar

Brugman, C., \& Lakoff, G. (1988). Cognitive typology and lexical networks. In S. Small, G. Cottrell, \& M. T. Tanenhaus (Eds.), Lexical ambiguity resolution (pp. 477-507). Palo Alto, CA: Morgan Kaufman.

Celce-Murcia, M., \& Larsen-Freeman, D. (1999). The grammar book: An ESL/EFL teacher's course (2 ${ }^{\text {nd }}$ ed.). Boston, 
MA: Heinle \& Heinle.

Conroy, M. A. (2018). Contextual factors in second language learning in a short-term study abroad programme in Australia. The Language Learning Journal, 46(3), 311-328. doi: https://doi.org/10.1080/09571736.2015.11 18643

Cooper, T. C. (1999). Processing of idioms by L2 learners of English. TESOL Quarterly, 33, 233-262. doi: https:// doi.org/10.2307/3587719

Cornell, A. (1985). Realistic goals in teaching and learning phrasal verbs. IRAL, 23, 269-280. doi: https://doi. org/10.1515/iral.1985.23.1-4.269

Cs'abi, S. (2004). A cognitive linguistic view of polysemy in English and its implications for teaching. In M. Achard \& S. Niemeier (Eds.), Cognitive linguistics, second language acquisition, and foreign language teaching (pp. 233-256). Berlin, Germany: Mouton de Gruyter. doi: https://doi.org/10.1515/9783110199857.233

Dagut, M., \& Laufer, B. (1985). Avoidance of phrasal verbs: A case for contrastive analysis. Studies in Second Language Acquisition, 7, 73-79. doi: https://doi.org/10.1017/S0272263100005167

Darwin, C. M., \& Gray, L. S. (1999). Going after the phrasal verb: An alternative approach to classification. TESOL Quarterly, 33, 65-93. doi: https://doi.org/10.2307/3588191

Dehé, N. (2002). Particle verbs in English: Syntax, information structure and intonation. Amsterdam, Netherlands: Benjamins. doi: https://doi.org/10.1075/la.59

Evans, V., \& Green, M. (2006). Cognitive linguistics: An introduction. Edinburgh, Scotland: Edinburgh University Press.

Fraser, J. B. (1976). The verb-particle combination in English. New York, NY: Academic Press.

Gardner, D., \& Davies, M. (2007). Pointing out frequent phrasal verbs: A corpus-based analysis. TESOL Quarterly, 41, 339-359. doi: https://doi.org/10.1002/j.1545-7249.2007.tb00062.x

Garnier, M., \& Schmitt, N. (2014). The PHaVE List: A pedagogical list of phrasal verbs and their most frequent meaning senses. Language Teaching Research, 19(6), 645-666. doi: https://doi.org/10.1177/1362168814559798

Garnier, M., \& Schmitt, N. (2016). Picking up polysemous phrasal verbs: How many do learners know and what facilitates this knowledge? System, 59, 29-44. doi: https://doi.org/10.1016/j.system.2016.04.004

Gibbs, R. W. (1994). The poetics of mind. Cambridge, MA: Cambridge University Press.

Goldberg, A. (1995). Constructions: A construction grammar approach to argument structure. Chicago, IL: University of Chicago Press.

Hulstijn, J.H., \& Marchena, E. (1989). Avoidance: Grammatical or semantic causes? Studies in Second Language Acquisition, 11, 241-255. doi: https://doi.org/10.1017/S0272263100008123

Jackendoff, R. (1997). The architecture of the language faculty. Cambridge, MA: MIT Press.

Jackendoff, R. (2002). English particle constructions, the lexicon, and the autonomy of syntax. In N. Dehé, R. Jackendoff, A. McIntyre \& S. Urban (Eds.), Verb-particle explorations (pp. 67-94). Berlin, Germany: Mouton de Gruyter. doi: https://doi.org/10.1515/9783110902341.67

Johnson, M. (1987). The body in the mind: The bodily basis of meaning, imagination and reason. Chicago, IL: Chicago University Press.

Karahan, P. (2015). The effect of conceptual metaphors on Turkish EFL learners' comprehension and production of phrasal verbs. International Journal of Linguistics and Communication, 3(1), 76-86. doi: https://doi. org/10.15640/ijlc.v3n1a10

Kissling, E. M. (2012). The effect of phonetics instruction on adult learners' perception and production of L2 sounds (Unpublished doctoral disseration). Georgetown University, Washington, DC. Retrievd from https://eric. ed.gov/?id=ED549285

Kovács, É. (2007). The traditional vs. cognitive approach to English phrasal verbs. Retrieved from http://www. uni-miskolc.hu/ philos/2011_tom_XVI_1/141.pdf

Kövecses, Z., \& Radden, G. (1998). Metonymy: Developing a cognitive linguistic view. Cognitive Linguistics, 9(1), 37-79. doi: https://doi.org/10.1515/cogl.1998.9.1.37

Kövecses, Z., \& Szabó, P. (1996). Idioms: A view from cognitive semantics. Applied Linguistics 17(3), 326-355. doi: https://doi.org/10.1093/applin/17.3.326

Lakoff, G. (1987). Women, fire, and dangerous things: What categories reveal about the mind. Chicago, IL: University of Chicago Press.doi: https://doi.org/10.7208/chicago/9780226471013.001.0001

Lakoff, G., \& Johnson, M. (1980). Metaphors we live by. Chicago, IL: University of Chicago Press.

Langacker, R. (1987). Foundations of cognitive grammar: Theoretical prerequisites. Stanford, CA: Stanford University Press.

Langacker, R. (1991). Foundations of cognitive grammar: Descriptive application. Stanford, CA: Stanford University Press 
Langacker, R. (2002). Concept, image, and symbol: The cognitive basis of grammar (2nd ed.). Berlin, Germany: Mouton de Gruyter.

Laufer, B., \& Eliasson, S. (1993). What causes avoidance in L2 learning: L1-L2 difference, L1-L2 similarity, or L2 complexity? Studies in Second Language Acquisition, 15, 35-48. doi: https://doi.org/10.1017/ S0272263100011657

Lazar, G. (1996). Using figurative language to expand students' vocabulary. ELT Journal, 50, 43-51. doi: https:// doi.org/10.1093/elt/50.1.43

Leech, G. (1997). Teaching and language corpora: A convergence. In A. Wichmann, S. Fligelstone, T. McEnery \& G. Knowles (Eds.), Teaching and language corpora (pp. 1-23). London, UK: Longman.

Liao, Y., \& Fukuya, Y. J. (2004). Avoidance of phrasal verbs: The case of Chinese learners of English. Language Learning, 54, 193-226. doi: https://doi.org/10.1111/j.1467-9922.2004.00254.x

Lindner, S. (1981). A lexico-semantic analysis of English verb-particle constructions with UP and OUT (Unpublished doctoral dissertation). University of California, San Diego, SD.

Lipka, L. (1972). Semantic structure and word-formation: Verb-particle constructions in contemporary English. Munich, Germany: Wilhelm Fink Verlag.

Littlemore, J., \& Low, G. (2006). Figurative thinking and foreign language learning. Hampshire, UK: Palgrave. doi: https://doi.org/10.1057/9780230627567

Liu, D. (2011). The most frequently used English phrasal verbs in American and British English: Amulticorpus examination. TESOL Quarterly, 45, 661-688. doi: https://doi.org/10.5054/tq.2011.247707

Liu,D., \& Myers,D.(2018).Themost-common phrasalverbswith theirkeymeaningsfor spokenandacademicwritten English: A corpus analysis. Language Teaching Research. doi: https://doi.org/10.1177/1362168818798384

Lu, Z., \& Sun, J. (2017). Presenting English polysemous phrasal verbs with two metaphor-based cognitive methods to Chinese EFL learners. System, 69, 153-161. doi: https://doi.org/10.1016/j.system.2017.07.016

Milošević, I., \& Pavlović, T. V. (2017). A cognitive-linguistic investigation of English phrasal verbs related to plants. Linguistics and Literature, 15(2), 219-233.

Moon, R. (1997). Vocabulary connections: Multi-word items in English. In N. Schmitt \& M. McCarthy (Eds.), Vocabulary: Description, acquisition and pedagogy (pp. 40-63). Cambridge, MA: Cambridge University Press.

Morgan, P. (1997). Figuring out figure out: Metaphor and the semantics of the English verb-particle construction. Cognitive Linguistics, 8, 327-357. doi: https://doi.org/10.1515/cogl.1997.8.4.327

Nation, I.S.P. (1990). Teaching and learning vocabulary. New York, NY: Newbury House.

Nhu, N., \& Huyen. P. (2009). Conceptual metaphor and its application in teaching phrasal verbs to English majors at Thuc Hanh High School, HCMC (Unpublished master's thesis). HCMC University of Education, HCMC, Vietnam. Retrieved from http://khoaanh.net/_upload/downloads_upload/894.pdf

Pelli, M. G. (1976). Verb Particle Constructions in American English. Zurich, Switzerland: Francke Verlag Bern.

Quirk, R., Greenbaum, S., Leech, G., \& Svartvik, J. (1985). A Comprehensive grammar of the English language. London, UK: Longman.

Rudzka, B., \&Ostyn, P. (2003). Word power: phrasal verbs and compounds. Berling, France: Walter De Gruyter GmbH \& Co. doi: https://doi.org/10.1515/9783110197235

Skehan, P. (1998). A cognitive approach to language learning. Oxford, UK: Oxford University Press.

Spring, R. (2018). Teaching phrasal verbs more efficiently: Using corpus studies and cognitive linguistics to create a particle list. Advances in Language and Literary Studies, 9(5), 125-139. doi: https://doi.org/10.7575/ aiac.alls.v.9n.5p. 125

Sroka, K. A. (1972). The syntax of English phrasal verbs. The Hague, Netherlands: Mouton. doi: https://doi. org/10.1515/9783110801378

Strong, B., \& Boers, F. (2019). The Error in Trial and Error: Exercises on Phrasal Verbs. TESOL Q, 53, 289-319. doi: https://doi.org/10.1002/tesq.478

Talebinejad, M. R., \& Sadri, E. (2013). Applying cognitive linguistics to teaching conceptual basis of up and down in phrasal verbs. Journal of Basic and Applied Scientific Research, 3(1), 333-340.

Talmy, L. (1985). Lexicalization patterns: Semantic structure in lexical form. In T. Shopen(Ed.), Language typology and syntactic description (pp.36-149). Cambridge, UK: CUP. doi: https://doi.org/10.1017/ cbo9780511618437.002

Taylor, J. (2002). Cognitive grammar. Oxford, UK: Oxford University Press.

Teng, M. F. (2018). The effect of focus on form and focus on forms instruction on the acquisition of phrasal verbs by Chinese students. Asian EFL Journal, 20(6), 145-173.

Trebits, A. (2009). The most frequent phrasal verbs in English language EU documents: A corpus-based analysis and its implications. System, 37(3), 470-481. doi: https://doi.org/10.1016/j.system.2009.02.012 
Tyler, A., \& Evans, V. (2003). The semantics of English prepositions: Spatial scenes, embodied meaning and cognition. Cambridge, UK: Cambridge University Press.

Tyler, A., \& Evans, V. (2004). Applying cognitive linguistics to pedagogical grammar: The case of over. In M. Achard \& S. Niemeier (Eds.), Cognitive linguistics, second language acquisition, and foreign language teaching (pp. 257-280). Berlin, Germany: Mouton de Gruyter. doi: https://doi.org/10.1515/9783110199857.257

van der Veer, R. (2000). Some reflections concerning Gal'perin's theory. Human Development, 43, 99-102. doi: https://doi.org/10.1159/000022663

Verspoor, M., \& Lowie, W. (2003). Making sense of polysemous words. Language Learning, 53, 547-586. doi: https://doi.org/10.1111/1467-9922.00234

Wang, H. C. (2009). Phrasal verbs and breadth of vocabulary knowledge in second language reading: An exploratory study. The Journal of Asia TEFL, 6(3), 201-226.

West, M. (1953). A general service list of English words. London, UK: Longman, Green \& Co.

White, B. J. (2012). A conceptual approach to the instruction of phrasal verbs. The Modern Language Journal, 96(3), 419-438. doi: https://doi.org/10.1111/j.1540-4781.2012.01365.x

Yasuda, S. (2010). Learning phrasal verbs through conceptual metaphors: A case of Japanese EFL learners.TESOL Quarterly, 44(2), 250-273. doi: https://doi.org/10.5054/tq.2010.219945

Zareva, A. (2016). Multi-word verbs in student academic presentations. Journal of English for Academic Purposes, 23, 83-98. doi: https://doi.org/10.1016/j.jeap.2016.07.001 


\section{Appendix A}

Name: Section:

Choose particles from the following box to complete the sentences below. Put only letters on the blanks.

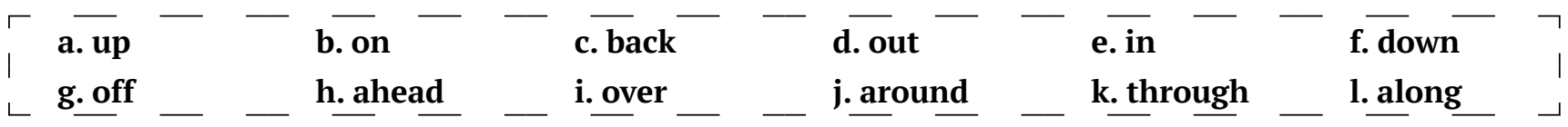

1. Father grabbed the thief and turned him to the police.

2. I wonder whether they will get this bill the Parliament.

3. The explorers set at 5 o'clock in the morning.

4. See if you can turn any evidence for his presence on the night of January.

5 . He curses and swears till his voice gives

6. I couldn't make what he was saying.

7. If your friend wants to come on the deal, he'll need to put a lot of money on the table.

8. We're putting a concert to raise money for cancer charities.

9. Opposition parties are threatening to bring the government.

10. To start up the business, they should each put $£ 50,000$.

Name: Section:

Choose particles from the following box to complete the sentences below.

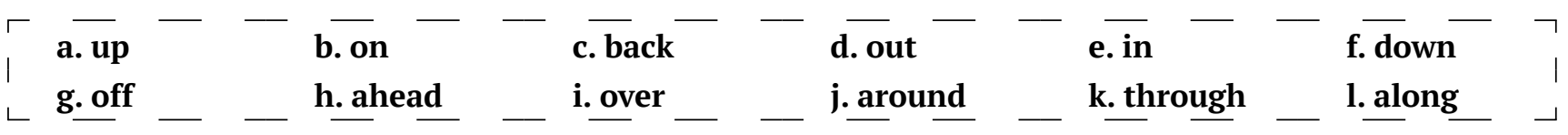

1. The company will have to sell assets to avoid bankruptcy.

2. He handed his hand to greet us.

3. This bitter medicine is hard to swallow

4. Though he did not believe her, he decided to hear her story to the end.

5 . The lawyer looked the document and disagreed with several points.

6. If you want to keep up your English, tune regularly to the $\mathrm{BBC}$.

7. Nobody knows as yet how the secret leaked

8. As the meeting was dragging , several members dozed off/dropped off.

9. The demand is such that the factory has to step production.

10. They closed the street because it is going to be re-surfaced. 